\section{Postharvest Quality of Early Season Grapefruit after Forced-air Vapor Heat Treatment}

\author{
W.R. Miller and R.E. McDonald \\ U.S. Department of Agriculture, Agricultural Research Service, 2120 \\ Camden Road, Orlando, FL 32803
}

Additional index words. Citrus paradisi, citrus, quarantine treatment, postharvest condition

\begin{abstract}
Marsh' and 'Ruby Red' grapefruit (Citrus paradisi Macf.) were harvested in Florida during Oct. and Nov. 1990, degreened in an ethylene chamber, exposed to vapor heat $(\mathrm{VH})$ treatment $(43.5 \pm 0.1 \mathrm{C}$ for $\approx 240 \mathrm{~min})$, and evaluated for deterioration in quality and development of injury after various storage regimes. Symptoms of aging averaged $6 \%$ and $8 \%$ of the surface on 'Ruby Red' and 'Marsh' fruit, respectively, and the VH treatment had reduced the incidence of aging by $45 \%$ after 5 weeks of storage (4 weeks at $16 \mathrm{C}$ plus 1 week at $21 \mathrm{C}$ ). Total decay, mostly stem-end rots (Diplodia spp. and Phomopsis spp.), remained relatively low $(\approx 5 \%)$ in both treated and nontreated fruit after 5 weeks of storage. The VH treatment had little effect on change in peel color during treatment or subsequent storage. After the final inspection, 'Marsh' fruit was higher in total soluble solids and titratable acidity than 'Ruby Red' fruit, but these quality indicators and $\mathrm{pH}$ were not affected by the VH treatment. VH treatment did not adversely affect the quality of 'Marsh' or 'Ruby Red' grapefruit harvested early in the season; hence, VH should be considered as a viable quarantine treatment for Florida grapefruit.
\end{abstract}

Quarantine regulations require that grapefruit exported from Florida to Japan and South Korea and for domestic shipments to Arizona, California, and Texas must be certified free from infestation by the Caribbean fruit fly (CFF) [Anastrepha suspensa (Loew)]. Approved quarantine treatments (Animal and Plant Health Inspection Service, 1976) for disinfestation of the CFF for Florida grapefruit include: 1) fumigation with methyl bromide, 2) cold treatment, and 3) harvesting fruit from fly-free zones. Each of these approved treatments are subject to certain commercial limitations in their usage. Methyl bromide causes peel injury at dosages needed to kill the CFF. Grapefruit conditioning and cold treatment (Hatton and Cubbedge, 1982) are recommended for use on fruit harvested after the arbitrary date of about 1 Jan. (considered by the trade as late-season fruit compared to early season fruit, which requires degreening), when fruit peel will tolerate the stress of cold treatment. Certified fly-free zones do not contain enough fruit to supply season-long export market demands for certified fly-free fruit. Therefore, for shipments that require quarantine treatment for the $\mathrm{CFF}$, shippers usually harvest from fly-free zones

\footnotetext{
Received for publication 25 Oct. 1991. Accepted for publication 2 Jan. 1992. Mention of a trademark, warranty, proprietary product, or vendor does not constitute a guarantee by the U.S. Dept. of Agriculture and does not imply its approval to the exclusion of other products or vendors that may also be suitable. The cost of publishing this paper was defrayed in part by the payment of page charges. Under postal regulations, this paper therefore must be hereby marked advertisement solely to indicate this fact.
}

early in the production season and apply the conditioning and cold treatment to grapefruit from other production areas harvested late in the season.

Recently, investigators have evaluated the entomological and horticultural feasibility of using various kinds of heat to develop alternative treatments for disinfesting grapefruit of the CFF and yet not cause physical or physiological damage to peel, pulp, or juice. Such treatments include: 1) immersing grapefruit in heated water (Gould, 1988; Miller et al., 1988; Sharp and Chew, 1987), 2) forced heated air (Sharp, 1989), and 3) forced vapor-heated air (Hallman et al., 1990; Miller et al., 1991). Vapor heat is not a new quarantine treatment for grapefruit. It was tested and used in 1929 to disinfest oranges and grapefruit shipped from Florida of the Mediterranean fruit fly (Ceratitis capitata Wiedemann), and against the Mexican fruit fly (A. ludens Loew) in Mexico (Baker et al., 1944). A vapor heat treatment of a constant $43.5 \mathrm{C}$, with an air flow rate of 0.4 $\mathrm{m}^{3} \cdot \mathrm{sec}^{-1}$ and relative humidity $(\mathrm{RH})$ near $100 \%$, until core temperature of fruit reaches and remains at 43.3 to $43.5 \mathrm{C}$ for $50 \mathrm{~min}$, provides security against the CFF (Hallman et al., 1990). This treatment did not injure 'Marsh' grapefruit harvested late in the 198889 season (Miller et al., 1991) or 'Marsh' or 'Ruby Red' (a thinner-peel cultivar) (Miller and McDonald, 1991) harvested later in the season from the 1990-91 crop year. The purpose of our present study was to determine if 'Marsh' and 'Ruby Red' grapefruit harvested early in the season, when the peel is less resistent to stress and requires degreening, will tolerate forced-air VH treatment without injury or quality deterioration.
On three occasions 'Marsh' and 'Ruby Red grapefruit, harvested from three separate groves in the Indian River production area of Florida, were obtained at the packinghouse from field bins within $24 \mathrm{~h}$ of picking. Fruit were not subjected to any postharvest application of fungicides. Fruit selected were free from defects and ranged in size (diameter) from 40 count $(10.0 \mathrm{~cm})$ to 36 count $(10.5 \mathrm{~cm})$ per standard-size citrus box. They were taken to the U.S. Horticultural Laboratory in Orlando, Fla., and held for $72 \mathrm{~h}$ in an environmentally controlled degreening room at $30 \mathrm{C} \pm 1 \mathrm{C}, 95 \% \mathrm{RH}$, with $5 \mathrm{ppm}$ ethylene. Fruitwere removed when the peel was yellow, as determined by visual inspection. After degreening, all fruit were placed at ambient conditions $(\approx 26 \mathrm{C})$ until they reached the same temperature. This usually took less than $12 \mathrm{~h}$. One-half of the fruit in each 'Marsh' and 'Ruby Red' lot was subjected to the VH treatment, the other half was not treated. The experimental forced-air test chamber (Gaffney and Armstrong, 1990; Gaffney et al., 1990) was set to maintain air at a near constant $43.5 \mathrm{C}$ at the fruit surface, with RH near $100 \%$ so that moisture condensed on the surface of fruit, and with an airflow rate of $0.4 \mathrm{~m} \cdot \mathrm{set}^{-1}$. Within the test chamber, 66 fruit were placed into each of four plastic bins $(56.5 \times 35.9 \times 27.3 \mathrm{~cm})$. The bins were interlocked into each other $\approx 2$ $\mathrm{cm}$ and had fully open tops and $78 \%$ mesh bottoms, forming a tunnel through which all air passed. Treatment continued until fruit center pulp temperatures reached $43.5 \mathrm{C}$ and had remained at $43.4 \pm 0.1 \mathrm{C}$ for $50 \mathrm{~min}$. During treatment, fruit and air temperatures were recorded at 5-min intervals. Fruit temperatures were monitored with thermocouples, inserted two each (center or $1 \mathrm{~mm}$ deep into the flavedo) into each of three fruit. Air temperatures were recorded on its entry into the chamber and $6 \mathrm{~mm}$ above the surface of three fruit located at the air exit side of the fruit mass under treatment. The fruit not treated with vapor heat were held at ambient conditions until the heat treatment was completed. When fruit were removed from the forced-air, vapor-heat test chamber, they were placed at ambient conditions until pulp temperatures equilibrated to $\approx 20 \mathrm{C}$. Fruit were washed with soap (Mold Strip 25; Fresh Mark, Ocoee, Fla.), and 1000 ppm thiabendazole (TBZ) was applied by drip system to onehalf of each cultivar/treatment combination. All fruit were then waxed (Citrus export wax; FMC, Lakeland, Fla.). The experiment was a $2 \times 2 \times 2$ factorial design with eight treatment combinations-'Marsh' or 'Ruby Red' grapefruit with or without vapor heat, and with or without TBZ. The fruit sample size for each treatment combination was three boxes of 40 fruit each; therefore, each test (replication) included 480 fruit of each cultivar. Fruit were packed in $0.028-\mathrm{m}^{3}(4 / 5$ bushel), full-telescoping, fiberboard export boxes with two ventilation holes on each long side panel for storage.

All fruit were inspected after treatment (initial) and reinspected after 2 or 4 weeks at $16 \pm 1 \mathrm{C}(\mathrm{RH} 90 \%)$ and finally after 1 
Table 1. Condition of 'Marsh' and 'Ruby Red' grapefruit treated with or without vapor heat (VH) and with or without thiabendazole (TBZ) $(1000 \mathrm{ppm})$ after 2 and 4 weeks of storage at $16 \mathrm{C}$ and after 1 additional week at $21 \mathrm{C}$.

\begin{tabular}{|c|c|c|c|c|c|c|c|c|}
\hline \multirow{2}{*}{$\begin{array}{c}\text { Cultivar }(\mathrm{CV}) \\
\text { and } \\
\text { treatment }\end{array}$} & & \multicolumn{5}{|c|}{ Fruit in category (\%) } & \multirow{2}{*}{$\begin{array}{l}\text { Appear- } \\
\text { ance } \\
\text { index }\end{array}$} & \multirow[b]{2}{*}{$\begin{array}{c}\text { 'a*' } \\
\text { Valuex }\end{array}$} \\
\hline & & Sound & $\begin{array}{c}\text { Slight }{ }^{2} \\
\text { aging }\end{array}$ & $\begin{array}{l}\text { Total } \\
\text { aging }\end{array}$ & SER $^{y}$ & $\begin{array}{l}\text { Total } \\
\text { decay }\end{array}$ & & \\
\hline \multicolumn{9}{|c|}{2 Weeks at $16 \mathrm{C}$} \\
\hline Marsh & & 96.6 & 2.0 & 2.4 & 0.9 & 1.1 & 1.1 & 0.6 \\
\hline Ruby Red & & 96.5 & 1.9 & 2.3 & 1.0 & 1.5 & 1.0 & --- \\
\hline $\mathrm{VH}$ & & 96.5 & 1.2 & 1.7 & 1.6 & 2.0 & 1.1 & 0.7 \\
\hline No VH & & 96.5 & 2.6 & 3.0 & 0.4 & 0.6 & 1.0 & 0.5 \\
\hline TBZ & & 96.3 & 1.9 & 1.9 & 1.6 & 2.0 & 1.0 & 0.8 \\
\hline No TBZ & & 96.7 & 2.8 & 2.8 & 0.4 & 0.6 & 1.1 & 0.4 \\
\hline Factors & $\mathrm{df}$ & & & & & & & \\
\hline$\overline{\mathrm{CV}}$ & $\overline{1}$ & $0.4^{\mathrm{NS}}$ & $0.4^{\mathrm{NS}}$ & $0.1^{\mathrm{NS}}$ & $0.4^{\mathrm{NS}}$ & $0.8^{\mathrm{NS}}$ & $0.1^{*}$ & $\ldots$ \\
\hline VH & 1 & $0.0^{\mathrm{NS}}$ & $34.7^{*}$ & $31.3^{*}$ & $28.1^{*}$ & $31.3^{*}$ & $0.0^{\mathrm{NS}}$ & $0.2^{\mathrm{NS}}$ \\
\hline TBZ & 1 & $3.1^{\mathrm{NS}}$ & $12.5^{\mathrm{NS}}$ & $14.7^{\mathrm{Ns}}$ & $28.1^{*}$ & $31.3^{*}$ & $0.1^{*}$ & $0.4^{\mathrm{NS}}$ \\
\hline $\mathrm{CV} \times \mathrm{VH}$ & 1 & $42.0^{*}$ & $42.0^{*}$ & $83.4^{*}$ & $5.6^{\mathrm{NS}}$ & $7.0^{*}$ & $0.0^{\mathrm{NS}}$ & -.. \\
\hline $\mathrm{VH} \times \mathrm{TBZ}$ & 1 & $28.1^{*}$ & $1.4^{\mathrm{NS}}$ & $2.2^{\mathrm{NS}}$ & $12.5^{*}$ & $14.7^{\mathrm{NS}}$ & $0.0^{\mathrm{NS}}$ & $0.5^{*}$ \\
\hline Error & $48(6)^{w}$ & 5.9 & 5.1 & 4.5 & 1.8 & 1.8 & 0.0 & 0.1 \\
\hline \multicolumn{9}{|c|}{4 Weeks at $16 \mathrm{C}$} \\
\hline Marsh & & 91.7 & 5.2 & 5.7 & 2.2 & 3.0 & 1.8 & 0.4 \\
\hline Ruby Red & & 93.8 & 2.9 & 3.7 & 2.1 & 3.1 & 1.5 & $\ldots$ \\
\hline $\mathrm{VH}$ & & 93.8 & 2.8 & 3.3 & 2.6 & 3.4 & 1.7 & 0.6 \\
\hline No VH & & 91.7 & 5.4 & 6.1 & 1.7 & 2.6 & 1.6 & 0.1 \\
\hline TBZ & & 92.6 & 3.5 & 4.2 & 2.7 & 3.7 & 1.7 & 0.6 \\
\hline No TBZ & & 92.9 & 4.6 & 5.1 & 1.6 & 2.3 & 1.6 & 0.2 \\
\hline Factors & df & & & & & & & \\
\hline$\overline{\mathrm{CV}}$ & $\overline{1}$ & $73.0^{*}$ & $94.5^{*}$ & $73.0^{*}$ & $0.4^{\mathrm{NS}}$ & $0.0^{\mathrm{NS}}$ & $1.3^{*}$ & -- \\
\hline $\mathrm{VH}$ & 1 & $73.0^{*}$ & $118.8^{*}$ & $145.9^{*}$ & $12.5^{\mathrm{NS}}$ & $12.5^{\mathrm{NS}}$ & $0.0^{\mathrm{NS}}$ & $0.7^{*}$ \\
\hline TBZ & 1 & $2.2^{\mathrm{NS}}$ & $19.5^{\mathrm{NS}}$ & $14.7^{\mathrm{NS}}$ & $22.2^{*}$ & $28.1^{*}$ & $0.0^{\mathrm{NS}}$ & $0.4^{\mathrm{NS}}$ \\
\hline $\mathrm{CV} \times \mathrm{VH}$ & 1 & $45.9^{\mathrm{NS}}$ & $313^{\mathrm{NS}}$ & $94.5^{*}$ & $5.6^{\mathrm{NS}}$ & $8.7^{\mathrm{NS}}$ & $0.1^{\text {NS }}$ &.-- \\
\hline $\mathrm{CV} \times \mathrm{TBZ}$ & 1 & $31.3^{\mathrm{NS}}$ & $31.3^{\mathrm{NS}}$ & $45.9^{*}$ & $5.6^{\mathrm{NS}}$ & $1.4^{\mathrm{NS}}$ & $0.2^{\mathrm{NS}}$ & --- \\
\hline $\mathrm{VH} \times \mathrm{TBZ}$ & 1 & $0.8^{\mathrm{NS}}$ & $14.7^{\mathrm{NS}}$ & $14.7^{\mathrm{Ns}}$ & $17.0^{*}$ & $22.2^{*}$ & $0.3^{\mathrm{NS}}$ & --- \\
\hline Error & $48(6)^{w}$ & 12.9 & 9.4 & 10.4 & 4.4 & 4.4 & 0.1 & 0.1 \\
\hline \multicolumn{9}{|c|}{$\begin{array}{l}4 \text { Weeks at } 16 \mathrm{C}+ \\
1 \text { week at } 21 \mathrm{C}\end{array}$} \\
\hline Marsh & & 88.6 & 6.8 & 7.8 & 3.3 & 4.1 & 1.9 & 0.4 \\
\hline Ruby Red & & 89.0 & 4.9 & 5.8 & 4.2 & 6.1 & 1.8 & $\ldots$ \\
\hline $\mathrm{VH}^{\circ}$ & & 89.8 & 4.2 & 4.8 & 4.4 & 6.2 & 1.9 & 0.8 \\
\hline No VH & & 87.8 & 7.5 & 8.8 & 2.9 & 4.0 & 1.9 & 0.1 \\
\hline TBZ & & 88.1 & 5.8 & 6.7 & 4.3 & 6.1 & 1.9 & 0.5 \\
\hline No TBZ & & 89.4 & 5.9 & 6.9 & 3.0 & 4.1 & 1.9 & 0.3 \\
\hline \multicolumn{9}{|l|}{ Factors } \\
\hline$\overline{\mathrm{CV}}$ & $\overline{1}$ & $2.2^{\mathrm{NS}}$ & $68.1^{*}$ & $68.1^{*}$ & $19.5^{\mathrm{Ns}}$ & $45.9^{*}$ & $0.1^{\mathrm{Ns}}$ & -- \\
\hline $\mathrm{VH}$ & 1 & $73.0^{\mathrm{NS}}$ & $200.0^{*}$ & $292.0^{*}$ & $45.9^{*}$ & $73.0^{*}$ & $0.0^{\mathrm{NS}}$ & $1.3^{*}$ \\
\hline TBZ & 1 & $31.3^{\mathrm{NS}}$ & $0.4^{\mathrm{NS}}$ & $1.4^{\mathrm{NS}}$ & $31.3^{*}$ & $45.9^{*}$ & $0.0^{\mathrm{NS}}$ & $0.1^{\mathrm{Ns}}$ \\
\hline $\mathrm{CV} \times \mathrm{VH}$ & 1 & $118.8^{*}$ & $138.9^{*}$ & $253.1^{*}$ & $14.7^{\mathrm{Ns}}$ & $25.1^{\mathrm{NS}}$ & $0.0^{\mathrm{NS}}$ & -- \\
\hline $\mathrm{CV} \times \mathrm{TBZ}$ & 1 & $4.3^{\mathrm{NS}}$ & $3.1^{\mathrm{NS}}$ & $5.6^{\mathrm{NS}}$ & $0.8^{\mathrm{NS}}$ & $0.1^{\mathrm{NS}}$ & $0.0^{\mathrm{NS}}$ & ... \\
\hline $\mathrm{VH} \times \mathrm{TBZ}$ & 1 & $10.5^{\mathrm{NS}}$ & $8.7^{\mathrm{NS}}$ & $8.7^{\mathrm{NS}}$ & $25.1^{\mathrm{Ns}}$ & $38.3^{*}$ & $0.0^{\mathrm{NS}}$ & $0.1^{\mathrm{NS}}$ \\
\hline Error & $48(6)^{w}$ & 22.1 & 15.1 & 17.0 & 8.0 & 8.4 & 0.1 & 0.1 \\
\hline
\end{tabular}

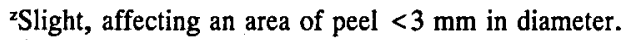

'SER = stem-end rots.

${ }^{x} \mathrm{CIE}(1976)$ ' $\mathrm{a}$ *' value, degree of green to red.

"Degrees of freedom for error term for ' $a$ ' value.

Ns, * Nonsignificant or significant mean squares at $P=0.05$.

additional week at $21 \pm 1 \mathrm{C}(\mathrm{RH} 95 \%)$. At each inspection fruit were evaluated for symptoms of aging, peel pitting, peel scald, decay, peel freshness, subjective firmness, and peel color. Symptoms of aging (stemend rind breakdown) (Smoot et al., 1971) were rated $1=$ slight, $2=$ moderate, or 3 $=$ severe, based on the area of peel affected. Aging symptoms rated slight (area $<3 \mathrm{~mm}$ in diameter) were scored but considered not to affect grade of fruit or to be objectionable to consumers, whereas areas scored moderate $(3$ to $6 \mathrm{~mm})$ or severe $(>6 \mathrm{~mm})$ were considered objectionable. Pitting and peel discoloration were rated $1=$ slight $(<10 \%)$, $2=$ moderate $(11 \%$ to $25 \%)$, or $3=$ severe fruit sample of 'Marsh' and 'Ruby Red' before degreening and from a separate 15 -fruit sample from each of the eight treatment combinations after the final inspection. Peel color was measured (Minolta Chroma Meter Model CR-200, with 8-mm sensor; Minolta, Osaka, Japan) from three premarked areas on five random fruit in each box of 'Marsh' grapefruit, with or without vapor heat or TBZ, after degreening and each inspection. Objective color measurements of 'Ruby Red' fruit were omitted due to the development of red blush on the peel. Total soluble solids (TSS) content, titratable acidity (expressed as percent citric acid), and $\mathrm{pH}$ were determined from juice of 'Marsh' and 'Ruby Red' before degreening, after heat treatment, and after 5 weeks of storage. Seven panelists scored (hedonic scale 0-100) flavor of juice from both cultivars, treated or not treated with $\mathrm{VH}$, after the final inspection.

All data for each of the condition and quality characteristics included in the study were averaged over the three replications and subjected to analysis of variance procedures (SAS, 1982) to test the main effects of cultivar, heat treatment, and TBZ and their interactions.

Significantly more symptoms of rind aging developed on 'Marsh' than on 'Ruby Red' fruit after 4 or more weeks of storage, and more on fruit without the $\mathrm{VH}$ treatment than on those treated (Table 1). The effect of VH on the development of rind aging generally depended on cultivar. Lesions caused by aging were characteristically located at the stem end of the fruit. The majority (more than $85 \%$ after 4 or more weeks of storage) of lesions from aging were rated slight, affecting $<3 \mathrm{~mm}$ of contiguous rind area. Vapor heat reduced and TBZ had no effect on the incidence of aging. All observed symptoms of aging affected $<9 \%$ of fruit of any treatment category, and most lesions were slight or did not downgrade fruit. Therefore, since the U.S. standards for grades of Florida grapefruit limit aggregated damage from rind breakdown to $<9.5 \mathrm{~mm}$ for U.S. No. 1 grade (U.S. Dept. of Agriculture, 1967), we did not consider this injury as detrimental to fruit grade or to sales.

Total decay incidence averaged $\approx 5 \%$ after the final inspection (Table 1). 'Ruby Red' fruit had significantly more $(30 \%)$ decay than did 'Marsh' fruit after 5 weeks of storage, and most decay was stem-end rot (Phomopsis spp. or Diplodia spp.). However, no practical conclusion can be made regarding decay, because the incidence of rots in all treatment combinations was low. The incidence of green mold (Penicillium spp.) was $<1 \%$, as were other miscellaneous rots, which were not categorized separately.

Fruit appearance decreased from fresh to fairly fresh during 5 weeks (4 weeks at 16C plus 1 week at 21C) of storage (Table 1). Although 'Ruby Red' was rated slightly fresher in appearance after 2 weeks of storage, there was no difference between cultivars after fruit were held 1 additional week at 21C. The CIE (1976) ' $a$ *' color value indicates that greenness of peel for 'Marsh' 
Table 2. Quality ${ }^{2}$ of grapefruit cultivars (CV) Marsh and Ruby Red before and after treatment with vapor heat $(\mathrm{VH})$ for 240 min at $43.5 \mathrm{C}$ or untreated, and after storage for 4 weeks at $16 \mathrm{C}$ plus 1 additional week at $21 \mathrm{C}$.

\begin{tabular}{|c|c|c|c|c|c|c|}
\hline $\begin{array}{l}\text { Cultivar } \\
\text { and } \\
\text { treatment }\end{array}$ & & $\begin{array}{l}\text { TSS } \\
(\%) \\
\end{array}$ & $\begin{array}{l}\text { TA } \\
(\%)\end{array}$ & $\mathrm{pH}$ & $\begin{array}{c}\text { Firmness } \\
(\mathrm{N})\end{array}$ & $\begin{array}{c}\text { Flavor } \\
\text { index }\end{array}$ \\
\hline \multicolumn{7}{|l|}{ Initial } \\
\hline Marsh & & 9.85 & 1.4 & 2.95 & 3.4 & $\ldots$ \\
\hline Ruby Red & & 8.90 & 1.2 & 2.97 & 3.6 & -.- \\
\hline Factors & $\underline{\mathrm{df}}$ & & & & & \\
\hline $\mathrm{CV}$ & $\overline{1}$ & $5.1^{*}$ & $13.5^{*}$ & $0.0^{\mathrm{NS}}$ & $0.3^{*}$ & $\cdots$ \\
\hline Error & 13 & 0.0 & 1.4 & 0.03 & 0.1 & $-\cdots$ \\
\hline \multicolumn{7}{|c|}{ Immediately after VH } \\
\hline Marsh & & 9.77 & 1.3 & 3.00 & -.- & ..- \\
\hline Ruby Red & & 8.82 & 1.2 & 3.01 & --- & -.- \\
\hline VH & & 9.35 & 1.3 & 2.97 & -.- & ..- \\
\hline No VH & & 9.23 & 1.3 & 3.05 & --- & --- \\
\hline Factors & $\underline{\mathrm{df}}$ & & & & & \\
\hline$\overline{\mathrm{CV}}$ & $\overline{1}$ & $5.4^{*}$ & $5.6^{*}$ & $0.0^{\mathrm{NS}}$ &.-- & $\cdots$ \\
\hline VH & 1 & $0.1^{\mathrm{NS}}$ & $0.5^{\mathrm{NS}}$ & $0.04^{*}$ & --. & ... \\
\hline Error & 14 & 0.1 & 0.7 & 0.02 & --- & $\cdots$ \\
\hline \multicolumn{7}{|c|}{$\begin{array}{l}4 \text { Weeks at } 16 C+ \\
1 \text { week at } 21 C\end{array}$} \\
\hline Marsh & & 10.1 & 1.3 & 3.09 & 3.0 & 83.2 \\
\hline Ruby Red & & 9.0 & 1.2 & 3.12 & 3.0 & 74.7 \\
\hline $\mathrm{VH}$ & & 9.6 & 1.2 & 3.08 & 2.9 & 79.3 \\
\hline No VH & & 9.6 & 1.2 & 3.11 & 3.0 & 78.6 \\
\hline \multicolumn{7}{|l|}{ Factors } \\
\hline$\overline{C V}$ & $\overline{1}$ & $7.9^{*}$ & $7.5^{*}$ & $0.01 *$ & $0.01^{\mathrm{NS}}$ & $431.8^{*}$ \\
\hline VH & 1 & $0.1^{\mathrm{NS}}$ & $0.0^{\mathrm{NS}}$ & $0.01^{*}$ & $0.01^{\mathrm{NS}}$ & $2.8^{\mathrm{NS}}$ \\
\hline Error & 14 & 0.1 & 0.8 & 0.0 & 0.001 & 16.0 \\
\hline
\end{tabular}

${ }^{\mathrm{T}} \mathrm{TSS}=$ Total soluble solids; $\mathrm{TA}=$ titratable acids; flavor index $>50$ is acceptable.

Ns, *Nonsignificant or significant mean squares at $P=0.05$.

fruit was not affected by VH or TBZ after 2 weeks of storage. 'Marsh' fruit treated with $\mathrm{VH}$ had slightly less green in the peel than non-VH-treated fruit after 4 and 5 weeks of storage. Because the difference in the ' $a$ *' value was less than one unit, the difference is probably not visible; therefore, it is considered slight. There was no difference in ' $\mathrm{L}^{*}$ ' or ' $\mathrm{b}$ ' ' color values among the main factors or their interactions for 'Marsh' fruit. No pitting or discoloration was observed on either 'Marsh' or 'Ruby Red' fruit before or after $\mathrm{VH}$ treatment or after any storage regime.

'Marsh' fruit averaged $\approx 11 \%$ and $8 \%$ higher in TSS and titratable acidity, respectively, than 'Ruby Red' fruit (Table 2). After VH treatment, fruit were slightly but significantly lower in $\mathrm{pH}$ than fruit not treated, and this difference remained throughout subsequent storage. After the terminal inspec- chemical treatment to complement that of harvesting from fly-free zones for early season fruit.

\section{Literature Cited}

Animal and Plant Health Inspection Service. 1976. (revised 1985). Plant protection and quarantine treatment manual. Section VI-T100. Animal and Plant Health Inspection Service, U.S. Dept. Agr., Washington, D.C.

Baker, A.C., W.E. Stone, C.C. Plummer, and M. McPhail. 1944. A review of studies on the Mexican fruit fly and related Mexican species. U.S. Dept. Agr. Misc. Publ, 531.

Gaffney, J.J. and J.W. Armstrong. 1990. Hightemperature forced-air research facility for heating fruits for insect quarantine treatments. J. Econ. Entomol. 83:1959-1964.

Gaffney, J.J., G.J. Hallman, and J.L. Sharp. 1990. Vapor heat research unit for insect quarantine treatments. J. Econ. Entomol. 83:1965-1971.

Gould, W.P. 1988. A hot water/cold storage quarantine treatment for grapefruit infested with the Caribbean fruit fly. Proc. Fla. State Hort. Soc. 101:190-192.

Hallman, G.J., J.J. Gaffney, and J.L. Sharp. 1990. Vapor heat treatment for grapefruit infested with Caribbean fruit fly (Diptera: Tephritidae). J. Econ. Entomol. 83:1475-1478.

Hatton, T.T. and R. Cubbedge. 1982. Conditioning Florida grapefruit to reduce chilling injury during low-temperature storage. J. Amer. Soc. Hort. Sci. 107:57-60.

Miller, W.R. and R.E. McDonald. 1991. Quality of stored 'Marsh' and 'Ruby Red' grapefruit after high-temperature, high-relative humidity, forced-air treatment. HortScience 86:1188-1191.

Miller, W.R., R.E. McDonald, G. Hallman, and J.L. Sharp. 1991. Condition of Florida grapefruit after exposure to vapor heat quarantine treatment. HortScience 26:42-44.

Miller, W.R., R.E. McDonald, T.T. Hatton, and M. Ismail. 1988. Phytotoxicity to grapefruit exposed to hot water immersion treatment. Proc. Fla. State Hort. Soc. 101:192-195.

SAS Institute. 1982. SAS user's guide: Statistics. SAS Institute, Cary, N.C.

Sharp, J.L. 1989. Preliminary investigation using hot air to disinfest grapefruit of Caribbean fruit fly immatures. Proc. Fla. State Hort. Soc. 102:157-159.

Sharp, J.L. and V. Chew. 1987. Time/mortality relationships for Anastrepha suspensa (Diptera: Tephritidae) eggs and larvae submerged in hot water. J. Econ. Entomol. 80:646-649.

Smoot, J.J., L.G. Houck, and H.B. Johnson. 1971. Market diseases of citrus and other subtropical fruits. Reprinted 1983. Agr. Res. Serv., U.S. Dept. Agr., Washington, D.C. Agr. Hdbk. 398.

U.S. Department of Agriculture. United States standards for grades of Florida grapefruit. 1967. U.S. Dept. Agr., Washington, D.C. 